
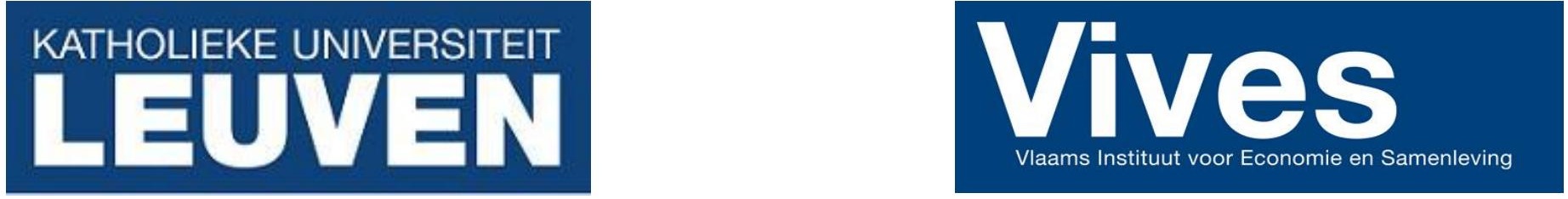

Naamsestraat 61 - bus 3550

B-3000 Leuven - BELGIUM

Tel : 32-16-326661

vives@econ.kuleuven.be

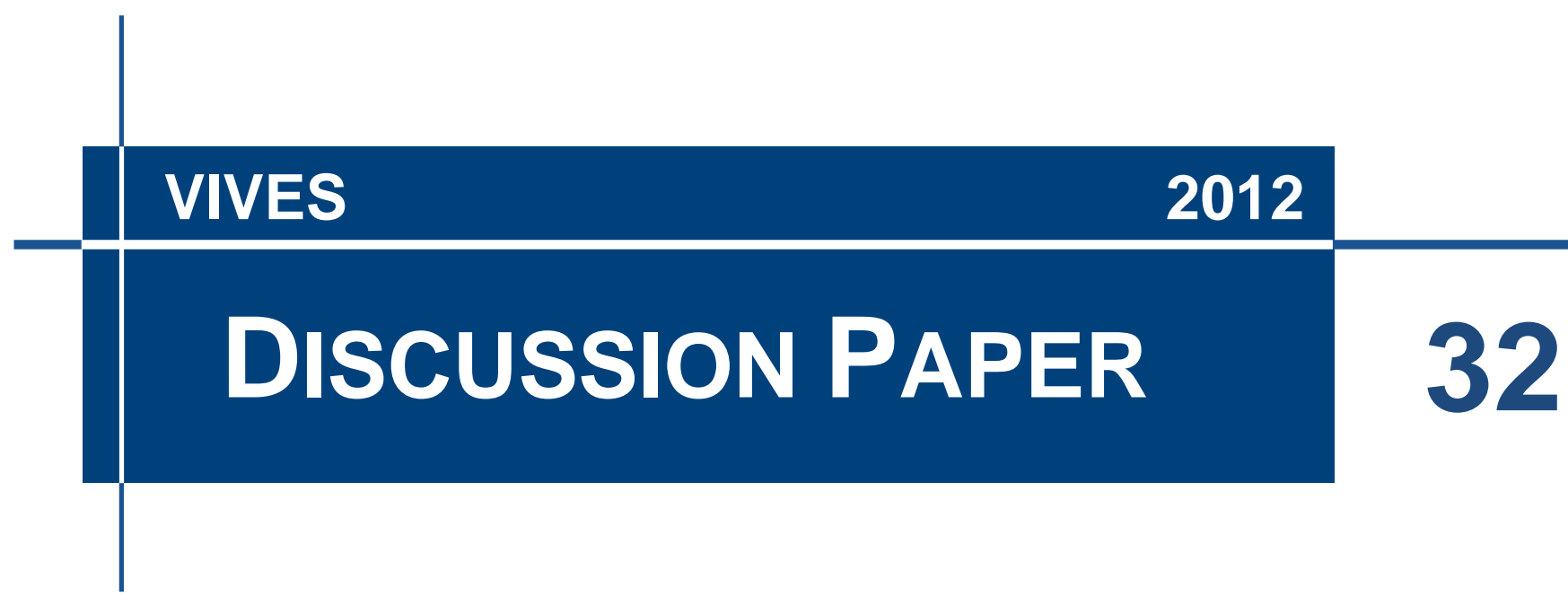

\title{
Start-up export intensity: An empirical investigation of the impact of absorptive capacity and business owner human and social capital
}

\author{
Jonas Debrulle
}

jonas.debrulle@econ.kuleuven.be

(tel) +3216324230 


\title{
START-UP EXPORT INTENSITY: AN EMPIRICAL INVESTIGATION OF THE IMPACT OF ABSORPTIVE CAPACITY AND BUSINESS OWNER HUMAN AND SOCIAL CAPITAL
}

\begin{abstract}
This study investigates the influence of business owner human and social capital on start-up export intensity. In addition, building on the knowledge-based view of the firm, we assume the relationships between owner characteristics and firm export activities to be moderated by the start-up's absorptive capacity, which designates its ability to acquire, assimilate and exploit new information. Flemish start-ups form this study's empirical setting. Our results indicate that start-up export intensity is (1) driven by the business owner's formal education and start-up experience, while (2) weakened by his/her accumulated management experience. Furthermore, we find evidence that start-up absorptive capacity significantly moderates the export impact of the owner's human capital. Finally, implications and opportunities for future research are suggested.
\end{abstract}

Keywords: Export intensity, business owner, human capital, social capital, organizational absorptive capacity. 


\section{START-UP EXPORT INTENSITY: AN EMPIRICAL INVESTIGATION OF THE IMPACT OF ABSORPTIVE CAPACITY AND BUSINESS OWNER HUMAN AND SOCIAL CAPITAL}

\section{INTRODUCTION}

The globalization of business and the need of many countries to support economic growth through accessing foreign markets have increased the expectations for small firms of all ages to become internationally active. This applies even more to firms in small market economies such as Norway, Denmark and Belgium (Julien and Ramangalahy, 2003). The decision to become internationally active is an important, yet difficult and risky decision for all firms (Eriksson and Chetty, 2003). Nevertheless, organizations proactively strive to internationalize more rapidly and at an earlier age (Sapienza et al., 2006). A question that has been intriguing both practitioners and researchers for quite some time now is how small new ventures are able to initiate, maintain and increase their international activities. As suggested by earlier research, being internationally successful demands from start-ups an effective and efficient acquisition and management of resources in general, and knowledge in particular (Armario et al., 2008; Burpitt and Rondinelli, 2000). These abilities enable new ventures to cope with the typical challenges associated with internationalization, such as internal coordination problems (Manolova et al., 2002), liabilities of foreignness (Hymer, 1976; Lu and Beamish, 2001), and the lack of foreign market knowledge (Eriksson and Chetty, 2003; Presutti et al., 2007; Yu et al., 2011).

Whichever theoretical framework is used to study the internationalization of new ventures (e.g. process theory versus the new venture theory of internationalization) (Autio et al., 2000), when competing internationally, knowledge, and the mechanisms to acquire, transfer and exploit knowledge, are considered vital sources of success and competitive advantage (Oviatt and McDougall, 2005; Rialp et al., 2005; Yli-Renko et al., 2001; Yu et al., 2011). As such, it is of key importance to focus on knowledge resources and capabilities that enable start-ups to internationalize successfully. Within this study, we consider the human and social capital of the business owner as well as the venture's absorptive capacity to be such elements. That is to say, we believe these elements represent sources of knowledge and/or knowledge-enabling capabilities that reinforce the internationalization of new ventures (Presutti et al., 2007; Sapienza et al., 2006; Yu et al., 2011). Specifically, this research 
argues that the start-up's export intensity is determined by (1) the personal knowledge accumulated by the owner(s) through human capital investments, (2) the information provided through his/her (or their) network of family, friends, acquaintances and professional contacts, and (3) the organization's ability to acquire, assimilate and exploit new knowledge (its absorptive capacity). We also investigate the impact of absorptive capacity on the owner's (anticipated) human and social capital-induced contribution to startup export intensity.

In this study, we make three contributions to the existing literature. First, we heed the call of Rialp et al. (2005) to address the little-researched topic of internationalization antecedents. In other words, by exploring the impact of internal knowledge resources and capabilities on start-up export intensity, we add to the understanding of possible drivers of the internationalization phenomenon within young ventures. Second, this study sheds light on how the organization's ability to acquire, assimilate and exploit new information affects the owner's capacity to direct business export activities. Although we recognize the owner as the start-up's 'primus inter pares', whose ideas, knowledge and vision propagate throughout the organization, we also acknowledge that at the firm level certain organizational processes occur (such as absorptive capacity) that vastly exceed any individual's span of control (Cohen and Levinthal, 1990). Third, by incorporating the knowledgebased theory of the firm into our research model, we seek to expand existing internationalization theories while exposing domain boundaries.

This article proceeds as follows. First, we address the concept of start-up internationalization and review the importance of knowledge within an international environment. Second, we focus on internationalization through export and explore how the business owner's human and social capital, together with the venture's absorptive capacity, might add to the start-up's export intensity. Third, we identify gaps in existing research and formulate several hypotheses. Fourth, we describe our research methodology with a special focus on sampling procedures and the measures used. Finally, we present and discuss our findings and conclude with some caveats and opportunities for future research. 


\section{START-UPS, INTERNATIONALIZATION AND KNOWLEDGE}

Before the 1990s, the habitat of start-ups was largely believed to be nationally restricted. More recently, it has become obvious that start-ups can be internationally active and successful (Presutti et al., 2007; Rialp et al., 2005; Yli-Renko et al., 2002). Intrigued by this remarkable evolution, Rialp et al. (2005) examined 38 modern studies on international new ventures and bornglobal start-ups. They conclude that the internationalization success of young ventures that become international at or near founding is triggered by changed market conditions, recent technological advancements, a growth in importance of worldwide networking and an increase in individual skills and capabilities. This urges Presutti et al. (2007) and Rialp et al. (2005) to question the traditional dimensions of the internationalization process, which date back to the 1970s and 1980s. According to these authors, it is no longer applicable to use the original interpretation of the internationalization process, whereby international activity is initiated late and incrementally in the firm's evolutionary path as a reaction to unsolicited export offers, while building on a solid domestic footing (Johanson and Vahlne, 1990).

In search of a new perspective on the internationalization phenomenon, researchers have employed various theoretical lenses to identify the unique resources, skills and capacities of new ventures that can explain their early international success. For instance, Peng (2001) and Zahra et al. (2003) build on the 'resource-based view' of the firm (Barney, 1991). In doing so, they connect the internationalization pattern of new ventures to the presence of valuable, rare, imperfectly imitable and non-substitutable resources, such as technology. In their study on UK technology-based start-ups, Burgel and Murray (2000) adopt the 'organizational capability perspective', whereby resources available to the international start-up are contrasted with (foreign) customer needs. In an attempt to discover a more overarching explicatory perspective, Autio et al. (2000), Barkema and Vermeulen (1998), Eriksson et al. (1997), McDougall et al. (1994) and Zahra et al. (2000) draw on a knowledgebased framework to explain venture internationalization decisions. More specifically, these authors make use of the 'knowledge-based view' of the firm. This view constitutes a stringent interpretation of the aforementioned resource-based view as it depicts knowledge creation and learning capabilities as the dominant drivers of the (young) firm's (international) development and growth. According to this perspective, the accumulation of knowledge, and its interpretation and rejuvenation, is what determines the organization's path of evolution (Yli-Renko et al., 2001). Knowledge is, therefore, regarded as the venture's main strategic asset, which enables it to 
produce a deeply rooted competitive advantage. Furthermore, within this knowledge-induced new venture theory of internationalization, the entrepreneur's knowledge is considered one of the key variable classes of interest to explain start-up internationalization (Autio et al., 2000). An example of knowledge known to make a difference for new venture export success is technological knowledge. Technological knowledge allows firms to improve product quality, strengthen innovative capacities and streamline operational efficiency (Knight and Cavusgil, 2004; Yu et al., 2011). Yet, this type of knowledge is essentially rooted in the problem-solving skills and critical thinking of the venture's entrepreneur and other human resources.

Apart from the consumption of internal knowledge bases, international activities such as export also require specific knowledge that new ventures do not yet possess and may find difficult to identify, acquire, assimilate and exploit (Knight and Cavusgil, 2004; Presutti et al., 2007). This suggests that start-ups also need to develop capabilities that allow them to acquire and build on knowledge that is necessary to for internationalization. New ventures are, therefore, dependent on their absorptive capacity, being the capability of acquiring, assimilating and exploiting new information and knowledge (Cohen and Levinthal, 1990). In summary, internal knowledge sources and the capacity to detect, obtain and use external knowledge could be considered essential to the start-ups' export activities.

\section{EXPORT AND BUSINESS OWNER HUMAN AND SOCIAL CAPITAL}

Despite the abundance of studies on the importance of knowledge for early internationalization, Rialp et al. (2005) argue that the need for empirical contributions on knowledge-related factors that give rise to start-up internationalization still exists. In this study, we attempt to heed this call for research on (knowledge-related) internationalization antecedents by exploring the role of the business owner in the export intensity of the start-up. We focus on the owner because of his/her pivotal role in the new venture. Not only is the owner at the center of the development of new combinations of knowledge (Thorpe et al., 2005), his/her education and experience also influence the nature and number of (international) strategic options considered for the emerging organization (Armario et al., 2008; Zahra et al., 2005). As a result, it is (commonly) the owner who merges available opportunities with the internationalization of the venture (Oviatt and McDougall, 2005), which renders him/her a principal force of the firm's export activities (Autio et al., 2000; Reuber and Fisher, 1997; Sousa et al., 2008). 
A business owner has two kinds of knowledge bases that he/she can employ to stimulate start-up development and internationalization: human capital and social capital (Becker, 1993; Davidsson and Honig, 2003; Nahapiet and Ghoshal, 1998). Human capital refers to knowledge and skills that individuals have accumulated through experience and/or education and that enable them to increase their cognitive abilities and enhance their efficiency and productivity (Becker, 1964; Davidsson and Honig, 2003; Ucbasaran et al., 2008). Human capital theory traditionally assumes that individuals with relatively more human capital are better equipped to perceive profitable opportunities and successfully exploit them (Schultz, 1959). Individuals can accrue additional knowledge and skills by investing in general and/or specific human capital (Becker, 1993; Bosma et al., 2004; Gimeno et al., 1997). While general human capital refers to all kinds of knowledge that is easily transferable across a wide range of situations (e.g. occupational alternatives, economic settings), specific human capital relates to knowledge and skills that are only applicable in a limited number of economic contexts (Gimeno et al., 1997; Ucbasaran et al., 2008).

General human capital, as reflected in formal education and management experience (Bates, 1990; Gimeno et al., 1997), is commonly considered a source of generic abilities, intelligence and skills applicable across a broad domain of activities. It broadens the individual's knowledge base and improves cognitive reasoning and problem solving skills (Chandler and Lyon, 2009; Smith et al., 2005). These cause the business owner to be more knowledgeable and confident, while reducing the perceived uncertainty associated with entering foreign markets and operating internationally. Davidsson and Honig (2003) argue that formal education renders entrepreneurs more prone to discover profitable opportunities (e.g. export opportunities). Management experience has been found to improve individual communication skills and negotiation power (Kim et al., 2006; Ucbasaran et al., 2008), which likely benefit the start-up when negotiating with foreign parties. According to Hatch and Dyer (2004) and Ucbasaran et al. (2008), business owners with relatively more general human capital are better equipped to tackle the complex problems inherent to diverse entrepreneurial activities, such as internationalization. By employing their superior cognitive abilities and business insight, highly educated and management-experienced owners are able to connect facts and pieces of information faster than their lower educated or less management-experienced colleagues. On top of that, general human capital has been argued to reflect a learning attitude, which involves an ongoing search about how to adapt to novel situations (De Clercq et al., 2005), with the latter being something the start-up is bound to encounter upon 
expanding internationally. Given these findings, we expect business owners to capitalize on their accumulated general human capital to quickly gain a profound understanding of the foreign market, efficiently recognize export opportunities, purposively create internationalization strategies, efficaciously manage foreign relations and effectively cope with problems that are innate to selling abroad. Hence, we believe that start-up owners with more general human capital, both in terms of formal education and management experience, are better equipped to underpin the export intensity of their venture, ceteris paribus:

Hypothesis 1: The business owner's general human capital is positively associated with start-up export intensity. This will be reflected in a positive effect of:

a) formal education, and

b) management experience.

Similar to general human capital, specific human capital has been argued to foster the ability to identify lucrative business opportunities (Davidsson and Honig, 2003). In addition, prior contributions have suggested that specific human capital benefits the owner upon evaluating and exploiting the already identified opportunity (Davidsson and Honig, 2003; Ucbasaran at al., 2008). Consistent with earlier work, we perceive the business owner's experience in the new venture's industry as well as his/her start-up experience as sources of specific human capital (e.g. Gimeno et al., 1997; Ucbasaran et al., 2008). Both industry and start-up experience produce knowledge about customers, suppliers, products and services which, while applicable to a limited scope of occupational alternatives (Gimeno et al., 1997), may not be border-restricted. Both instill the owner with procedural and, therefore, often cross-border knowledge on how to perform a particular task, on the pitfalls that may lie ahead and on actions that should not be taken (West and Noel, 2009). With respect to industry experience, Davidsson and Honig (2003) also suggest that it teaches business owners to 'read' the market and anticipate its changes. Through his/her specific experience, a business owner may discover how to deal with suppliers and customers, how to collect resources and how to market products and services (Shane and Khurana, 2003; Ucbasaran et al., 2008). We expect these skills and experiences to be equally useful in an international and domestic context because the knowledge accumulated is strongly related to the knowledge required to successfully enter foreign markets. Accordingly, based on the above findings, we believe that a business owner will be able to employ his/her specific human capital to advance the export activities of the start-up. It is paramount for any internationalizing 
start-up to effectively identify, evaluate and, if feasible, exploit export opportunities, to anticipate changes in foreign markets and to rapidly develop an international 'modus operandi'. Therefore, we expect that business owners who are used to opportunity recognition, evaluation and exploitation, who are capable of fathoming competitive strategies and know how to properly approach potential associates, will be valuable to the start-up's export intensity. Building on earlier research that maintains that both industry and start-up experience foster these abilities, we posit that:

Hypothesis 2: The business owner's specific human capital is positively associated with start-up export intensity. This will be reflected in a positive effect of:

a) industry experience, and

b) start-up experience.

Business owners can also build knowledge by investing in social capital. Social capital relates to the ability to benefit from networks, memberships and community-based relationships through the provision of tangibles and intangibles (Davidsson and Honig, 2003; Nahapiet and Ghoshal, 1998). Researchers generally distinguish between two types of social capital: bridging and bonding social capital. Bridging social capital, or loose network relationships (weak ties) with, for instance, other professionals, functions as an interface for the exchange of otherwise unavailable information and scarce resources. Bonding social capital, or associations with family and close friends (strong ties), is rooted in a collective, interpersonal trust and can equip the owner with permanent access to a limited supply of specific resources (e.g. advice, aid) (Davidsson and Honig, 2003; Granovetter, 1985).

Davidsson and Honig (2003) conclude that the owner's bridging and bonding social capital significantly add to the identification and exploitation of business opportunities. Not only does social capital expose business owners to new ideas, different views and market shifts, it also provides them with a network to procure crucial resources and knowledge (Aldrich and Zimmer, 1986; Oviatt and McDougall, 2005) that may be required for internationalization. Because start-ups only have access to a limited amount of resources, the decision to consume them has to be thoroughly considered. As a consequence, elaborate market studies and customer surveys are often regarded as too expensive. Yet, instead of blindly estimating (changes in) customer demands, the market and/or the environment, start-ups may find the social capital of a powerful individual such as the business owner instrumental in obtaining critical information regarding foreign projects 
(Arrègle et al., 2007). Moreover, as start-ups can influence the development of social capital, it may be one of their most efficient means of foreign knowledge acquisition (Nahapiet and Ghoshal, 1998; Presutti et al., 2007).

Given the limited resources available to new ventures, and their ability to capitalize on the owner's social capital to acquire (international) tangible and intangible assets, we expect the export activities of the start-up to benefit from the bridging and bonding social capital accumulated by its owner. With respect to intangibles, business owner social capital may allow the venture to access specific information that is necessary to successfully do business internationally and which is otherwise difficult to locate or acquire (Knight and Cavusgil, 2004). For instance, a parent-entrepreneur might teach the owner how to effectively penetrate a niche market (bonding social capital). Also, a colleague-entrepreneur could inform the start-up owner on the conditions he/she negotiated with a common supplier (bridging social capital). Regarding tangible assets, owner relationships with (foreign) investors or venture capitalists (bridging social capital) may provide the startup with the necessary financial capital to procure critical machinery (enabling the production of products intended for export). Likewise, the owner's family and friends (bonding social capital) might supply the start-up with permanent access to an ad hoc additional workforce, which could come in handy when faced with extra demand due to internationalization. In all, we posit:

Hypothesis 3: The business owner's social capital is positively associated with start-up export intensity. This will be reflected in a positive effect of:

a) bridging social capital, and

b) bonding social capital.

Though we expect the owner to function as a powerful and necessary source of knowledge to the start-up's internationalization effort, we also believe that the assimilation and use of knowledge throughout the firm is likely to pose additional challenges to the venture. In order to successfully face these challenges, start-ups require a well-developed absorptive capacity. Absorptive capacity denotes the venture's ability to acquire new information, assimilate that information and use it to commercial ends (Cohen and Levinthal, 1990). It refers to a firm-level ability that can be transferred from one market to another in the firm's international expansion (Eriksson and Chetty, 2003). Today, more than ever, knowing how to effectively consume new knowledge largely conditions the international success and competitive advantage of a business. Yli-Renko et al. (2002) maintain that firms expand internationally because they are able to learn and employ these learning 
processes more efficiently than other businesses. Likewise, McDougall et al. (1994) and Oviatt and McDougall (1997) place knowledge processes at the heart of the newly founded, internationally evolving venture. Given the predominant role of knowledge in the internationalization process, we expect that the acquisition, assimilation and exploitation of information represents a means to get ahead of both foreign and local international competitors (Liao et al., 2003). A well-developed absorptive capacity should allow the start-up to improve its market responsiveness and its ability to effectively develop foreign market-specific products and services. Absorptive capacity also provides the foundation for continued learning in an international environment that might strengthen the firm's competitive position on the foreign market (Armario et al., 2008; Hitt et al., 2006). As a result, Burpitt and Rondinelli (2000) and Julien and Ramangalahy (2003) denote the firm's absorptive capacity as one of the determinant variables associated with the decision to start exporting, and its subsequent success. Consistent with these authors, and in line with the arguments above, we propose that the level of the new venture's absorptive capacity is positively linked with its export intensity.

Hypothesis 4: A start-up's absorptive capacity is positively associated with its export intensity.

So far, we have argued that (1) knowledge is a vital value-adding resource of organizations, especially of those operating in an international environment (Yli-Renko et al., 2002), (2) the business owner represents an important source of knowledge to the start-up's internationalization effort, and (3) absorptive capacity largely determines the competitive advantage the start-up can yield from knowledge. Combining these arguments leads us to believe that the information and knowledge provided by the business owner through his/her human and social capital might have a stronger influence on the export activities of the start-up if the latter knows how to acquire, assimilate and exploit this information and knowledge. In other words, we expect the business owner's impact on the international activity of the start-up to be dependent on the firm's capacity to deal with this owner-induced information and knowledge. Although the owner's human and social capital may represent distinct, valuable reservoirs of knowledge, and even channels for knowledge flow, we assume that the firm-level capacity to identify, build on, and expand that knowledge will strengthen their internationalization impact. As a result, we posit that the more the absorptive capacity of the start-up is evolved, the more the owner will be able to employ his/her accumulated capital to affect its export intensity. Hence: 
Hypothesis 5: Start-up absorptive capacity acts as a positive moderator of the relationship between the business owner's accumulated capital and start-up export intensity. This will be reflected in a positive moderation of the effect of:

a) human capital, and

b) social capital.

Figure 1 graphically summarizes this study's hypothesized relationships.

Figure 1 Summary of research hypotheses

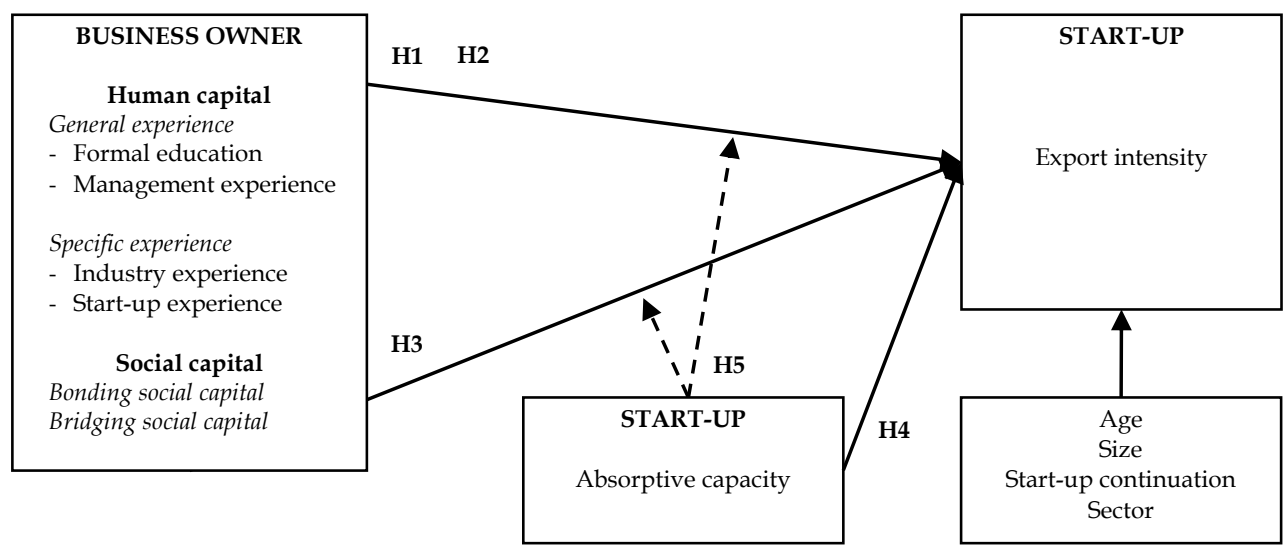

\section{METHODOLOGY}

\section{$\underline{\text { Sampling procedures }}$}

This study builds on an extensive cross-sectional survey on start-ups located in Flanders, Belgium, called START 2007. This is a biennial population survey of Flemish incorporated companies aged between one and three years, with a minimum of one and a maximum of forty-nine employees at the moment of measurement. From a content point of view, the survey's questions focused on various owner- and venture-related characteristics, practices and abilities. The survey's targeted respondents were the owners of the start-ups. Prior internationalization studies on new ventures have traditionally focused on high-technology start-ups or on businesses within high-tech sectors (e.g. Autio et al., 2000; Burgel and Murray, 2000; McDougall et al., 1994; Presutti et al., 2007; Zahra et al., 2000). Yet, recent research has revealed that (early) internationalization is not necessarily reserved for high-tech sectors. In fact, born-globals or early internationalizing ventures in smaller countries (such as Belgium) are more often found in non-high-tech sectors (Rialp et al., 2005). That's why, in order to broaden the understanding of the early internationalization phenomenon, and to expand the applicability of our 
results, we accommodated our sample for both high- and low-tech international start-ups operating in various high- and low-tech sectors (manufacturing, transportation and professional services). As a result, this study also includes 'less glamorous' sectors (Manolova et al., 2002), for which the unique source of advantage is often rooted in the owner's capital resources (Brush and Chaganti, 1999).

In 2007, the total research population of Flemish start-ups that satisfied START inclusion conditions consisted of 3251 firms. Due to obsolete company data, 301 of these start-ups could not be reached. Out of the 2950 remaining start-ups, 525 ventures completed and returned the questionnaire. The total survey response rate is, therefore, $17.8 \%$, which is comparable to that of other surveys of small business owners (Baron and Tang, 2011; Menon et al., 1999; Sousa et al., 2008). As a result of our sector focus, the sample was reduced to 249 usable observations, of which 116 start-ups (47\%) appeared to be internationally active. Because we made use of listwise exclusion during statistical procedures, only cases with no values missing on any of the variables were retained, resulting in a final sample of 98 start-ups. Respectively $36(36.7 \%)$ and 53 (54.1\%) start-ups were active in the manufacturing and professional services sector. The remainder (9 start-ups, 9.2\%) consisted of transportation companies. To check for non-response bias, we compared respondent firms with non-respondent firms on organization size (number of employees), age and industry. The results did not reveal any significant differences. We subsequently used those same variables to check for selection bias, whereby the start-ups included in our analyses were weighed against those not included (e.g. because of missing values on one or more of the variables). Again, no significant differences emerged.

\section{$\underline{\text { Measures }}$}

Export intensity. We adopt the measure of export intensity previously used by Julien and Ramangalahy (2003) and Madsen (1987), namely, the amount of exports expressed as a percentage of the total sales.

Absorptive capacity. Estimating absorptive capacity is subject to much controversy. In the past, researchers have operationalized absorptive capacity by means of R\&D investments, patents, organizational age and size (Mowery et al., 1996; Muscio, 2007; Tsai, 2001). However, not only do these proxies induce the reification of the absorptive capacity construct (Lane et al., 2006), they also fail to capture its underlying complex nature (Liao et al., 2003). 
In this study we measure absorptive capacity using a construct representing (1) the acquisition of external information, (2) the assimilation of acquired information throughout the business, and (3) its successful exploitation and application in commercial actions (Lane et al., 2006; Liao et al., 2003). Similar to Armario et al. (2008), Liao et al. (2003) and Maes and Sels (forthcoming), we opt for a market oriented measure of the start-up's capacity to make use of information from its environment. Market knowledge is known to be a motivating factor for firms to become internationally active (Yu et al., 2011). A market oriented approach of absorptive capacity is, therefore, particularly appropriate for examining firm internationalization. Besides, because of their limited resources, start-ups are frequently compelled to be more market oriented (Liao et al., 2003). Their restricted resources impede the execution of customer preference analyses or wide-scale market scanning, so start-ups often have to rely on direct contacts with their customers and organizational network as an external source of market information and customer demands (Keh et al., 2007). Coincidentally, such market intelligence not only sheds light on current customer demands but also adds to the company's understanding of (future) customer needs (Maes and Sels, forthcoming; Verhees and Meulenberg, 2004).

The scale items used to measure market oriented absorptive capacity are adapted from Kohli et al. (1993) and Maes and Sels (forthcoming). Respondents were asked to rate a five-point Likert scale on six statements regarding market and customer information processing (Cronbach's alpha $=$ .803). In view of employing market intelligence as a measure for absorptive capacity, all items were set up to capture the intensity with which market information is absorbed (e.g. 'We periodically review our product development efforts to ensure that they are in line with what customers want') (Maes and Sels, forthcoming). Using the factor formula suggested by Maes et al. (2005), the scale ranges from 0 to 100. This formula is outlined in Appendix $\mathrm{B}$ with all items and factor loadings.

General and specific human capital. In accordance with prior research (Bates, 1990; Gimeno et al., 1997), we used the highest level of formal education and the number of years of management experience as measures of the business owner's general human capital. Possible answers on the education scale ranged from primary education (1) to doctorate (6). In the case of multiple business owners, we determined the average level of formal education. We consider management experience a proxy of work experience, which is commonly measured as the number of years of employment. However, similar to Bates (1990), we believe management experience can be perceived 
as a level of achievement reached in employment, thereby giving it more value compared with using years of employment. To examine specific human capital, we asked the owners for their total number of years of industry experience and whether or not they had already actively participated in the process of creating a new business. The latter was coded one if at least one of the business owners of the start-up possessed such experience. Unlike the process for rating formal education, we opt for an aggregate measure of management and industry experience whenever multiple business owners are present. Our underlying rationale for choosing an average (in the case of education) or aggregate (in the case of experience) measure is the following: because of the idiosyncratic nature of (management and industry) experience, two business owners each with five years of experience will have accumulated a larger combined amount of knowledge than a single colleague with five years of experience, ceteris paribus. Even if these business owners have been active within the same industry, their odds of having different experiences (and building different knowledge) are considerable. Conversely, with respect to education, we perceive an owner's level of formal education as a proxy of his/her intelligence level. Because levels of intelligence are impracticable to add up, we cannot maintain that three business owners with secondary schooling (scale position $=2$ ) are as intelligent as one business owner with a PhD (scale position =6). Overall, it was determined that adopting an average measure for formal education and an aggregate one for management and industry experience was preferable.

Bridging and bonding social capital. We determined business owner social capital using two factors. Respondents were asked to rate four statements on the possible benefits for the start-up that were extracted from their network of friends, family and acquaintances, as well as four statements on similar benefits extracted from their network of professional contacts or business network. Possible answers varied from entirely disagree (1) to entirely agree (5). Using the formula suggested by Maes et al. (2005), we created a bonding social capital factor (Cronbach's alpha $=.694$ ) and bridging social capital factor (Cronbach's alpha $=.851$ ) with scale ranges from 0 to 100 . Once again, the adopted formula is outlined in Appendix B with all items and factor loadings.

Control variables. To isolate our hypotheses from other rival explanations and to minimize extraneous variation, we included the (average) age of the business owner(s), firm size, age of the business activities, start-up continuation and sector dummy variables as control variables. We measured organizational size in terms of the number of employees and owners active 
within the firm. Although all start-ups in our sample are between one and three years of (legal) age, not all of them consist of novo start-ups (e.g. takeover of a bankrupt business). This implies that business activities could have been carried out before the current organization was established. Therefore, we control for the actual age of the business activities as well as for start-up continuation. The latter is done by including a dummy variable ('start-up continuation') indicating whether or not the business activities were already operational before the current venture was legally established. Lastly, we introduced a series of dummy variables to control for the different market conditions within each sector. Two dummies were included in our analyses, using the manufacturing sector as a reference category.

\section{Measurement validity tests}

To exclude concerns of common-method variance and to examine the construct, convergent and discriminant validity of the social capital and absorptive capacity measures, we used the following approaches. The design of the questionnaire minimizes possible common-method variance effects since social capital and absorptive capacity items were not offered to the respondent immediately after each other. Instead, open-ended and other types of questions were interspersed throughout the questionnaire. This prevents respondents from developing a response pattern that is linked to Likert or semantic differential scales (Podsakoff et al., 2003).

Upon developing the social capital and absorptive capacity measures, Harman's single-factor test was used to test for common-method variance. This technique basically assumes that if a substantial amount of commonmethod variance is present, either a single factor will emerge from a factor analysis containing all predictor items or one general factor will account for the majority of the covariance among the measures (Podsakoff et al., 2003). Out of the factor analysis, three factors with eigenvalues greater than one emerged (accounting for 59\% of the variance). In the unrotated factor structure, no general factor was apparent (the first factor represented $31 \%$ of the variance). Based on the above, we conclude that there is no concern for the presence of substantial common-method variance within our data.

Construct validity was established by developing measures from wellgrounded theory (Barringer and Bluedorn, 1999). We refer to the measurement section (see above) for any additional details. Confirmatory factor analysis was used to assess the convergent and discriminant validity of the social capital (bridging/bonding) and absorptive capacity measures. We 
first analyzed an unconstrained model of the three constructs with each item loading solely on the factor for which it was an intended indicator. The fit of this model is good (GFI = .90; Bentler's Comparative Fit Index $=.93$ ). All items load significantly on their proposed factor (listed in Appendix B), which satisfies the convergent validity test (Anderson and Gerbing, 1988). Following Anderson and Gerbing (1988), we then examined the discriminant validity of the measures by constraining the correlation between each pair of constructs to one in consecutive models (three constructs means three constrained models, each with the correlation of a unique pair of constructs set to one). The difference between the chi-squared value of the unconstrained model and that of each constrained model also has a chi-squared distribution with one additional degree of freedom. If this pair-wise difference exceeds 3.84 (the 5\% critical value), then discriminant validity is said to be established. The chisquared differences vary from 37.17 to 61.77 and are, therefore, well above 3.84, demonstrating the discriminant validity of our social capital and absorptive capacity measures.

\section{$\underline{\text { Statistical procedures }}$}

Hierarchical regression analyses are used as the statistical procedure to test our hypotheses. The variables were mean-centered before creating the interaction terms with absorptive capacity. Because of the skewed nature of the dependent variable, we adopted the natural log transformation of export intensity as a response variable. We used the SPSS statistical package. The highest VIF-statistic encountered is 2.330, which is well below the recommended maximum value of five (Kleinbaum et al., 1998; Moreno and Casillas, 2008). This demonstrates the likely absence of multicollinearity.

\section{RESULTS}

Table 1 lists the means, standard deviations and bivariate correlations of this study's variables. All correlations are well below .80 in absolute value, which is again an indication against the possible presence of multicollinearity (Hair et al., 1998). The results of the hierarchical regression analyses are listed in Table 2. Model 1 of Table 2 represents the 'control model', which includes only the control variables. Models 2 to 4 relate to the human capital indicators and/or social capital indicators, together with the control variables. In Model 5 the moderator variable is added. Finally, Models 6 to 11 test the significance of the hypothesized interaction terms. 
Table 1 Descriptive statistics and correlations

\begin{tabular}{|c|c|c|c|c|c|c|c|c|c|c|c|c|c|c|c|c|}
\hline Variables & Mean & S.D. & 1 & 2 & 3 & 4 & 5 & 6 & 7 & 8 & 9 & 10 & 11 & 12 & 13 & 14 \\
\hline 1. Export intensity (Ln) & 2.83 & 1.36 & 1 & & & & & & & & & & & & & \\
\hline 2. Business owner age (avg.) & 41.22 & 7.17 & .023 & 1 & & & & & & & & & & & & \\
\hline 3. Age of business activities & 7.69 & 10.96 & -.124 & .019 & 1 & & & & & & & & & & & \\
\hline 4. Firm size & 8.43 & 9.14 & -.011 & .119 & .179 & 1 & & & & & & & & & & \\
\hline 5. Start-up continuation & .52 & .50 & .096 & -.096 & $.469^{* *}$ & -.096 & 1 & & & & & & & & & \\
\hline 6. Manufacturing & .37 & .49 & $-.246^{*}$ & -.023 & $.340^{* *}$ & .090 & .138 & 1 & & & & & & & & \\
\hline 7. Transportation & .09 & .29 & .097 & -.052 & -.066 & -.042 & -.190 & $-.242^{*}$ & 1 & & & & & & & \\
\hline 8. Professional services & .54 & .50 & .182 & .052 & $-.291^{* *}$ & -.062 & -.024 & $-.827^{* *}$ & $-.345^{* *}$ & 1 & & & & & & \\
\hline 10. Management experience & 17.31 & 12.74 & $-.281^{* *}$ & $.473^{* *}$ & .063 & .053 & -.104 & .114 & .143 & -.193 & -.174 & 1 & & & & \\
\hline 11. Industry experience & 21.82 & 17.28 & -.127 & $.401^{* *}$ & -.067 & $.331^{* *}$ & -.161 & -.093 & -.007 & .094 & -.016 & $.529^{* *}$ & 1 & & & \\
\hline 12. Start-up experience & .52 & .50 & .092 & $.293^{* *}$ & -.141 & .104 & $-.227^{*}$ & $-.243^{*}$ & .022 & $.222^{*}$ & .122 & $.294^{* *}$ & $.307^{* *}$ & 1 & & \\
\hline 13. Bonding social capital & 22.70 & 20.92 & -.167 & -.183 & .024 & -.171 & -.137 & .090 & .067 & -.126 & .073 & .086 & -.128 & -.087 & 1 & \\
\hline 14. Bridging social capital & 35.78 & 25.43 & -.071 & -.129 & .075 & .013 & .010 & -.157 & -.135 & $.231^{*}$ & .090 & .037 & .095 & $.212^{*}$ & $.222^{*}$ & 1 \\
\hline 15. Absorptive capacity & 49.36 & 21.27 & .161 & $-.236^{*}$ & -.140 & 187 & -.053 & -.015 & -.060 & .049 & .134 & -.190 & -.001 & .088 & .180 & $.240^{*}$ \\
\hline
\end{tabular}

**. Correlation is significant at the .01 level (two-tailed) - * Correlation is significant at the .05 level (two-tailed). 
Table 2 Results of hierarchical regression models of start-up export intensity

\begin{tabular}{|c|c|c|c|c|c|}
\hline Variables & Model 1 & Model 2 & Model 3 & Model 4 & Model 5 \\
\hline \multicolumn{6}{|l|}{ Control variables } \\
\hline Business owner age (avg.) & .040 & .174 & .012 & .141 & .169 \\
\hline Age of business activities & -.168 & -.190 & -.140 & -.177 & -.135 \\
\hline Firm size & .058 & .052 & .037 & .036 & -.002 \\
\hline Start-up continuation & $.228^{\dagger}$ & $.242^{*}$ & .196 & $.219 \dagger$ & $.202^{\dagger}$ \\
\hline Transportation & $.206^{+}$ & $.246^{*}$ & $.200^{\dagger}$ & $.242 *$ & $.248^{*}$ \\
\hline Professional services & $.211^{\dagger}$ & .027 & $.218^{\dagger}$ & .020 & .050 \\
\hline \multicolumn{6}{|l|}{ Human capital } \\
\hline Formal education level & & $.178^{\dagger}$ & & $.198^{*}$ & $.174^{\dagger}$ \\
\hline Management experience & & $-.345^{* *}$ & & $-.316^{* *}$ & $-.287^{*}$ \\
\hline Industry experience & & -.049 & & -.056 & -.067 \\
\hline Start-up experience & & $.147^{\dagger}$ & & $.145^{\dagger}$ & .125 \\
\hline \multicolumn{6}{|l|}{ Social capital } \\
\hline Bonding social capital & & & -.100 & -.090 & -.116 \\
\hline Bridging social capital & & & -.063 & -.026 & -.055 \\
\hline \multicolumn{6}{|l|}{ Moderator } \\
\hline Absorptive capacity (AC) & & & & & $.151^{\dagger}$ \\
\hline \multicolumn{6}{|c|}{ Two-way interactions involving human capital } \\
\hline \multicolumn{6}{|l|}{ Formal education level x AC } \\
\hline \multicolumn{6}{|c|}{ Management experience $\times \mathrm{AC}$} \\
\hline \multicolumn{6}{|l|}{ Industry experience $x \mathrm{AC}$} \\
\hline \multicolumn{6}{|l|}{ Start-up experience $x \mathrm{AC}$} \\
\hline \multicolumn{6}{|c|}{ Two-way interactions involving social capital } \\
\hline \multicolumn{6}{|c|}{ Bonding social capital x AC } \\
\hline \multicolumn{6}{|l|}{ Bridging social capital $\times \mathrm{AC}$} \\
\hline F-Change & 1.706 & $3.806^{* *}$ & .752 & $2.657^{* *(a)}$ & $1.901^{\dagger}$ \\
\hline Adjusted $\mathrm{R}^{2}$ & .042 & .147 & .037 & .136 & .145 \\
\hline
\end{tabular}

Standardized coefficients are shown (two-tailed, with directional hypothesis entries one-tailed); $\mathrm{N}=98$; (a) = On top control variables (Model 1); ${ }^{* * *}$. Significant at the .001 level _ **. Significant at the .01 level — *. Significant at the .05 level †. Marginally significant at the .10 level. 
Table 2 Results of hierarchical regression models of start-up export intensity (continued)

\begin{tabular}{|c|c|c|c|c|c|c|}
\hline Variables & Model 6 & Model 7 & Model 8 & Model 9 & Model 10 & Model 11 \\
\hline \multicolumn{7}{|l|}{ Control variables } \\
\hline Business owner age (average) & .175 & .176 & .188 & .184 & .169 & .184 \\
\hline Age of business activities & -.156 & -.125 & -.131 & -.114 & -.136 & -.161 \\
\hline Firm size & -.002 & .013 & -.032 & -.032 & -.002 & .006 \\
\hline Start-up continuation & $.206^{\dagger}$ & $.230^{\dagger}$ & .175 & .167 & $.203^{\dagger}$ & $.221^{\dagger}$ \\
\hline Transportation & $.255^{*}$ & $.263^{*}$ & $.254^{*}$ & $.232^{*}$ & $.247^{*}$ & $.244^{*}$ \\
\hline Professional services & -.003 & .050 & .055 & .005 & .050 & .065 \\
\hline \multicolumn{7}{|l|}{ Human capital } \\
\hline Formal education level & $.176^{\dagger}$ & $.203^{*}$ & $.162^{\dagger}$ & $.163^{\dagger}$ & $.175^{\dagger}$ & $.177^{\dagger}$ \\
\hline Management experience & $-.344^{* *}$ & $-.256^{*}$ & $-.302^{*}$ & $-.369^{* *}$ & $-.287^{*}$ & $-.290^{*}$ \\
\hline Industry experience & -.045 & -.077 & -.083 & -.014 & -.067 & -.070 \\
\hline Start-up experience & .129 & $.145^{\dagger}$ & .128 & $.138^{\dagger}$ & .126 & .118 \\
\hline \multicolumn{7}{|l|}{ Social capital } \\
\hline Bonding social capital & -.091 & -.111 & -.131 & -.102 & -.115 & -.111 \\
\hline Bridging social capital & -.014 & -.055 & -.043 & -.056 & -.056 & -.049 \\
\hline \multicolumn{7}{|l|}{ Moderator } \\
\hline Absorptive capacity (AC) & .118 & $.147^{\dagger}$ & $.149^{\dagger}$ & $.150^{\dagger}$ & $.150^{\dagger}$ & .133 \\
\hline \multicolumn{7}{|c|}{ Two-way interactions involving human capital } \\
\hline Formal education level x AC & $-.184^{*}$ & & & & & \\
\hline Management experience $x \mathrm{AC}$ & & $.174^{*}$ & & & & \\
\hline Industry experience $\times \mathrm{AC}$ & & & $-.132 \dagger$ & & & \\
\hline Start-up experience $\times A C$ & & & & $-.226^{* *}$ & & \\
\hline \multicolumn{7}{|c|}{ Two-way interactions involving social capital } \\
\hline Bonding social capital x AC & & & & & -.005 & \\
\hline Bridging social capital $\times \mathrm{AC}$ & & & & & & -.080 \\
\hline F-Change & $3.438^{*}$ & $3.119^{*}$ & $1.736^{\dagger}$ & $5.474^{* *}$ & .003 & .571 \\
\hline Adjusted $\mathrm{R}^{2}$ & .169 & .166 & .153 & .189 & .135 & .141 \\
\hline
\end{tabular}

Standardized coefficients are shown (two-tailed, with directional hypothesis entries one-tailed); $\mathrm{N}=98$;

***. Significant at the .001 level - **. Significant at the .01 level - *. Significant at the .05 level -

†. Marginally significant at the .10 level. 
Hypothesis 1 suggested that the business owner's general human capital is positively associated with start-up export intensity. Model 2 of Table 2 shows that business owners with higher levels of formal education indeed significantly stimulate the export intensity of their venture $(\beta=.178)$. Conversely, the regression coefficient of management experience is significant yet negative ( $\beta=-.345)$, suggesting that business owners with higher levels of management experience increasingly hinder the export intensity of their venture, ceteris paribus. Therefore, while hypothesis 1a is corroborated by our results, hypothesis $1 b$ is not.

Hypothesis 2 proposed that the business owner's specific human capital is positively associated with start-up export intensity. Yet, we learn from Model 2 of Table 2, that only start-up experience exerts a significant positive influence on the start-up's export intensity $(\beta=.147)$. The owner's industry experience appears to be insignificantly related to start-up export intensity $(\beta=-.049 ; p>.10)$. Our findings, thus, only offer support for hypothesis $2 b$, not for hypothesis $2 \mathrm{a}$.

Hypothesis 3 stated that the business owner's social capital is positively associated with start-up export intensity. Looking at Model 3 of Table 2, we notice that the relationship between the owner's bridging social capital and start-up export intensity is insignificant $(\beta=-.063 ; \mathrm{p}>.10)$, as is the relationship between bonding social capital and start-up export intensity $(\beta=-.100 ; p>.10)$. Consequently, we find no support for hypotheses $3 a$ and $3 b$.

According to hypothesis 4, we could expect the venture's absorptive capacity to be positively related to its export intensity. Model 5 of Table 2 provides support for this hypothesis. The regression coefficient of absorptive capacity on export intensity is positive and significant $(\beta=.151)$. Thus, start-ups with a better developed ability to acquire, assimilate and exploit information seem to be able to internationalize more effectively.

Hypothesis 5 suggested that start-up absorptive capacity acts as a positive moderator of the relationship between the business owner's accumulated (human and social) capital and the start-up's export intensity. We expect the association of the owner's accumulated capital to the venture's export intensity to be stronger for start-ups with high absorptive capacity compared with those with low absorptive capacity. However, Models 6 to 9 of Table 2 seem to suggest that start-up absorptive capacity negatively moderates the impact of the owner's human capital on export intensity. As illustrated in 
Figures 2 to 5, the relationship between the owner's human capital and export intensity is indeed inconsistent with our expectations formulated in hypothesis $5 \mathrm{a}$. While start-up absorptive capacity adjusts the effect of the owner's management experience $(\beta=.174)$ from strongly negative within start-ups with low absorptive capacity to moderately negative within organizations with high absorptive capacity, it deteriorates the export impact of the owner's (level of) formal education $(\beta=-.184)$, industry experience $(\beta=-.132)$ and start-up experience $(\beta=-.226)$.

Figure 2 Interaction effect of owner formal education and absorptive capacity on start-up export intensity

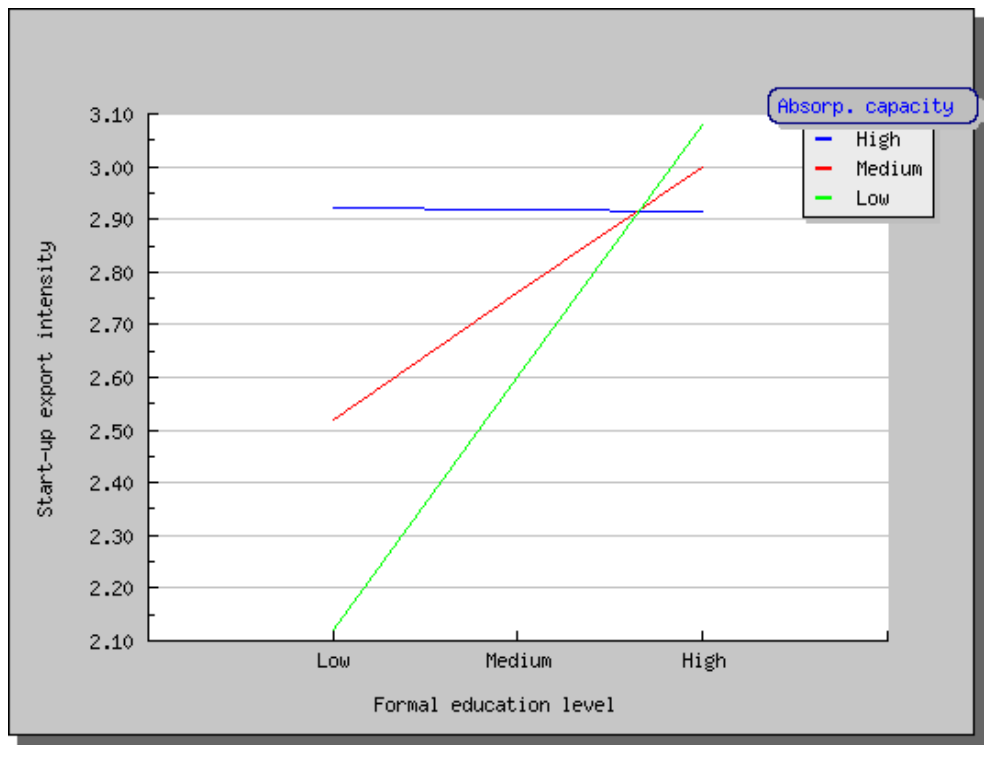

Figure 3 Interaction effect of owner management experience and absorptive capacity on start-up export intensity

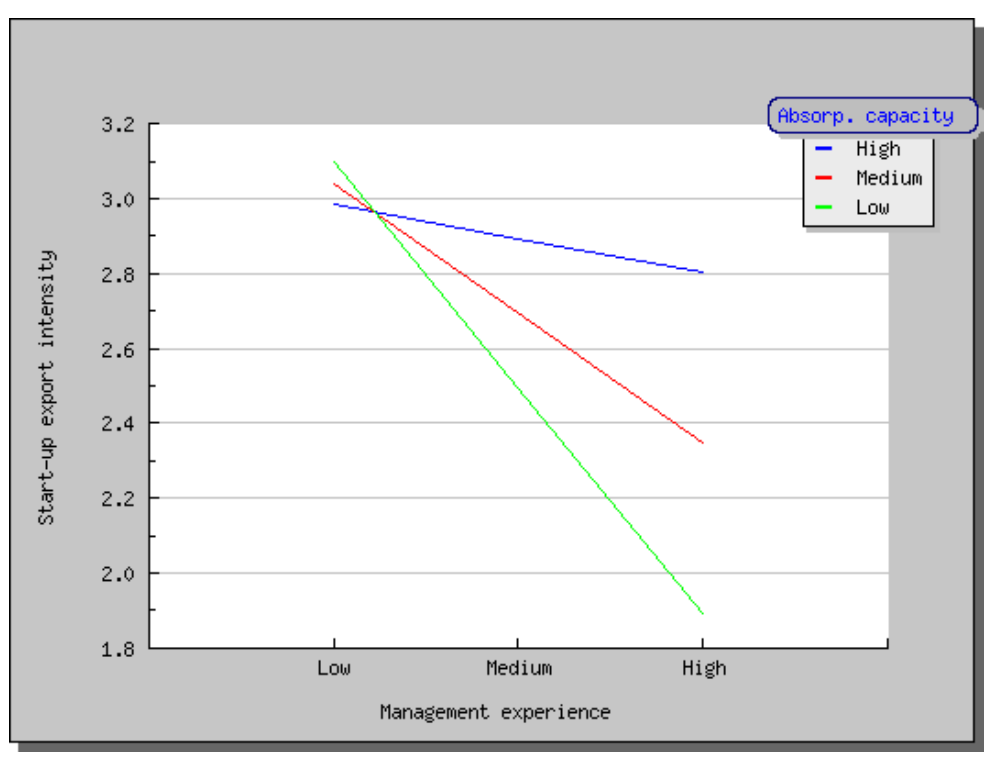


Figure 4 Interaction effect of owner industry experience and absorptive capacity on start-up export intensity

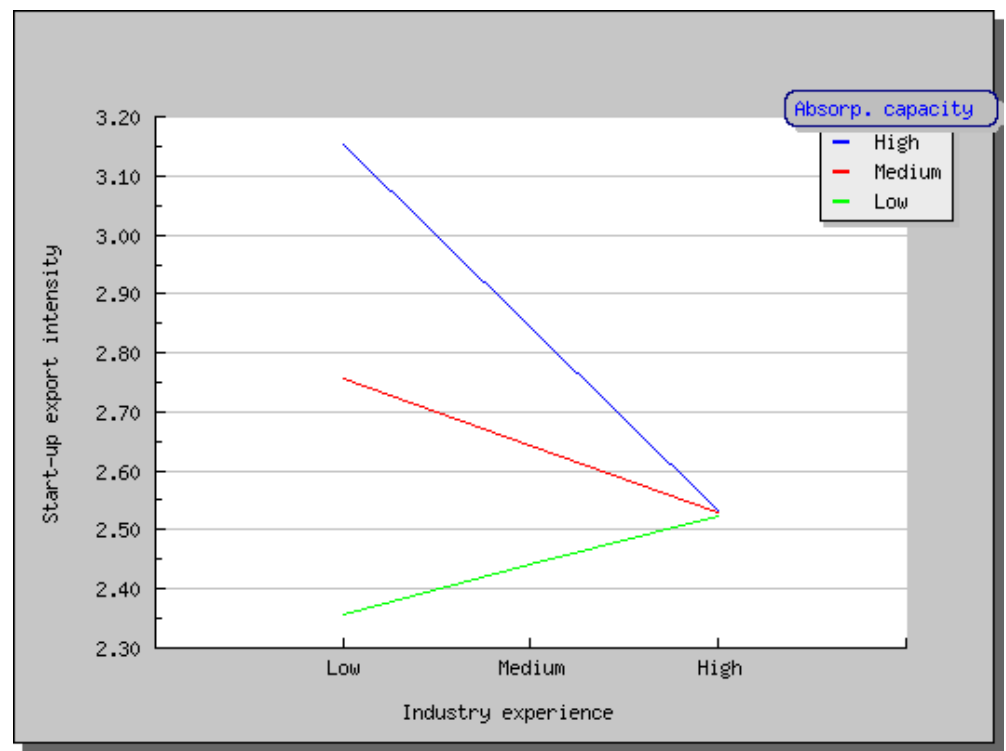

Figure 5 Interaction effect of owner start-up experience and absorptive capacity on start-up export intensity

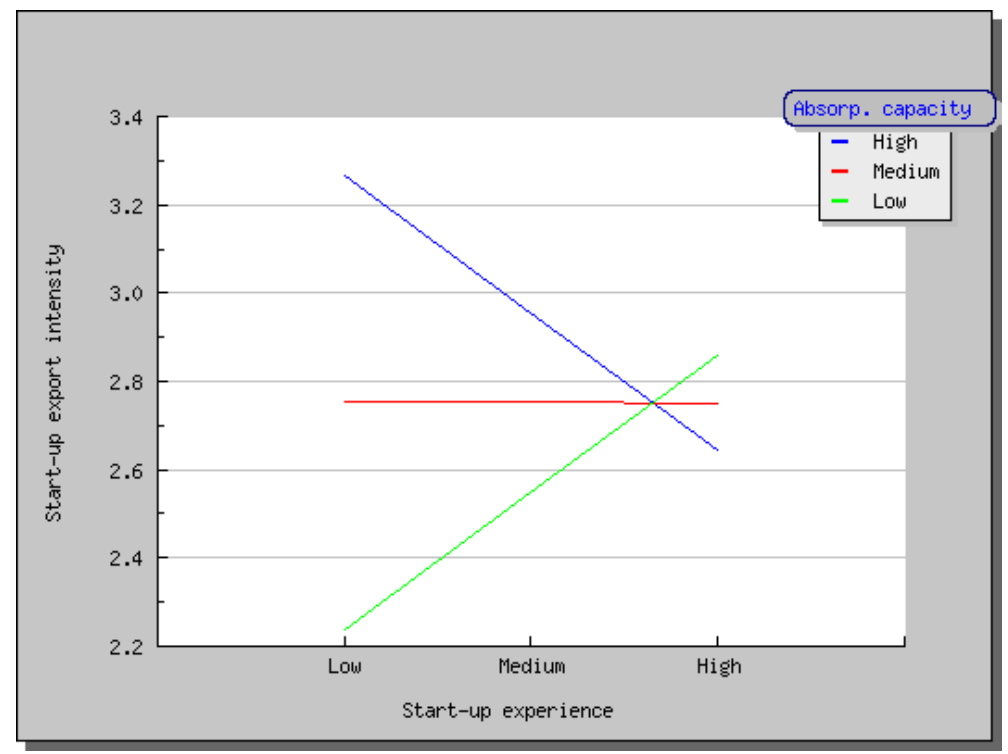

Next to the impact of absorptive capacity on the relationship between the owner's human capital and start-up export intensity, we also estimated its influence on the export effect of the business owner's (bridging and bonding) social capital. Models 10 and 11 of Table 2 reveal no evidence of any social capital moderation. That is, the cross-products involving the owner's bonding social capital $(\beta=-.005 ; p>.10)$ and bridging social capital $(\beta=-.080 ; p>.10)$ both appear insignificant. Hence, hypothesis $5 \mathrm{~b}$ is not corroborated by our results. 
Table 3 provides a summary of this study's hypotheses and results.

Table 3 Study hypotheses and results

\begin{tabular}{|c|c|c|}
\hline \multicolumn{2}{|c|}{ Hypothesis } & \multirow{2}{*}{$\begin{array}{l}\text { Finding } \\
\text { Supported }\end{array}$} \\
\hline $1 \mathrm{a}$ & $\begin{array}{l}\text { The business owner's general human capital is positively associated with } \\
\text { start-up export intensity. This will be reflected in a positive effect of } \\
\text { formal education. }\end{array}$ & \\
\hline $1 b$ & $\begin{array}{l}\text { The business owner's specific human capital is positively associated with } \\
\text { start-up export intensity. This will be reflected in a positive effect of } \\
\text { management experience. }\end{array}$ & Not supported \\
\hline $2 a$ & $\begin{array}{l}\text { The business owner's specific human capital is positively associated with } \\
\text { start-up export intensity. This will be reflected in a positive effect of } \\
\text { industry experience. }\end{array}$ & Not supported \\
\hline $2 b$ & $\begin{array}{l}\text { The business owner's specific human capital is positively associated with } \\
\text { start-up export intensity. This will be reflected in a positive effect of } \\
\text { start-up experience. }\end{array}$ & Supported \\
\hline $3 a$ & $\begin{array}{l}\text { The business owner's social capital is positively associated with start-up } \\
\text { export intensity. This will be reflected in a positive effect of bridging } \\
\text { social capital. }\end{array}$ & Not supported \\
\hline $3 b$ & $\begin{array}{l}\text { The business owner's social capital is positively associated with start-up } \\
\text { export intensity. This will be reflected in a positive effect of bonding } \\
\text { social capital. }\end{array}$ & Not supported \\
\hline 4 & $\begin{array}{l}\text { A start-up's absorptive capacity is positively associated with its export } \\
\text { intensity. }\end{array}$ & Supported \\
\hline $5 a$ & $\begin{array}{l}\text { Start-up absorptive capacity acts as a positive moderator of the relationship } \\
\text { between the business owner's accumulated capital and start-up export } \\
\text { intensity. This will be reflected in a positive moderation of the effect of } \\
\text { human capital. }\end{array}$ & Not supported \\
\hline $5 b$ & $\begin{array}{l}\text { Start-up absorptive capacity acts as a positive moderator of the relationship } \\
\text { between the business owner's accumulated capital and start-up export } \\
\text { intensity. This will be reflected in a positive moderation of the effect of } \\
\text { social capital. }\end{array}$ & Not supported \\
\hline
\end{tabular}

\section{DISCUSSION}

The objective of this study was to empirically examine the impact of business owner human and social capital on start-up export intensity. We subsequently tested general and specific human capital, bridging and bonding social capital, and their interaction with absorptive capacity as antecedents of export intensity. Five main hypotheses were developed and tested. Support for the hypotheses was partial. We discuss our findings in three sections: general human capital, specific human capital and social capital.

General human capital. Focusing on the business owner's general human capital, we found a significant and positive effect of formal education on startup export intensity, together with a significant but negative effect of management experience. Other than the above main effects, Figures 2 and 3 demonstrated that the part of the owner's export influence that originates from his/her general human capital declines as the organization's ability to 
acquire, assimilate and exploit knowledge increases. Regarding the direct contribution of formal education, we discern a possible explanation in the work of Cooper et al. (1994). According to these authors, higher educated entrepreneurs accumulate more maturity, discipline and self-confidence during their education, which renders them better equipped than their lower educated colleagues for the various complexities that accompany the task of running a business (e.g. internationalization issues). This implicitly suggests that the entrepreneurial added value of soft skills accumulated by education exceeds that of explicit knowledge. In order to validate this line of thought in an international context, there must be further research on the impact of education and educational components on international activity.

Contrary to the findings about formal education, management experience did not corroborate its hypothesized effect. Instead, a negative main effect on export intensity emerged. Unsure as to what mechanisms determine this outcome, we discern two possible explanations. First, it might be that some sort of risk aversion, which is induced by management experience, negatively influences start-up export intensity. That is to say, management experience may urge business owners to restrict the scope of their venture to an environment familiar to them, as they already know from prior practice that they possess sufficient stock-in-trade and supervisory skills to take up this environment's inherent challenges. However, we cannot forget that starting a new business also invites the owner to take risks, which weakens the above argument. We, therefore, consider a second, less radical explanation: it may be that the owners in our sample temporarily prioritize national business development over any export project. In order not to bite off more than they can chew, start-up business owners might temporarily disregard any export opportunities or opt to first explore the feasibility of other (less risky) internationalization modi (e.g. license, cooperation). Given that our sample accommodates different industries, in which international activity is no 'conditio sine qua non', we believe that postponing export endeavors is likely behavior. But one could argue that such prioritization of business activities is equally conditioned by the economic climate. That is, when faced with an economic decline or recession, the owner might be unable to further postpone any (international) development if the start-up is to survive. Additional research should explore whether the effect of management experience is inspired by risk aversion, export postponement or another mechanism. Furthermore, from a broader perspective, the extent to which international activities are determined by macro-economic forces should also be examined. 
Apart from the above main effects, our findings also suggested that the part of the owner's export influence that stems from his/her general human capital weakens, from being quite strong within start-ups with low absorptive capacity, to being moderate (management experience) or marginal (formal education) within organizations with high absorptive capacity. Not sure as to what mechanisms drive this outcome, we reach back to the original assumptions and propositions about the absorptive capacity construct as formulated by Cohen and Levinthal (1990). These authors argue that an organization's absorptive capacity builds on the 'individual absorptive capacity' of its members. More specifically, similar to organizations, individuals are able to gather information and put new knowledge into memory. Afterwards, they can recall and use this knowledge to generate new insights, thereby cumulatively creating an individual knowledge base and absorptive capacity (Cohen and Levinthal, 1990). Upon transferring this understanding of the individual level to the firm's level, Cohen and Levinthal (1990) posit that the organization's absorptive capacity capitalizes on the insights, know-how and expertise of all of the firm's constituents, including the owner and employees. Therefore, any internationalization influence that originates from a single individual will first be contrasted with the organization's already accumulated knowledge, which (to some extent) unites the knowledge accrued by all of the firm's members. As a result, the direct influence of the business owner on start-up export intensity could be conditioned by the organization's knowledge base and (the level of) its ability to acquire, assimilate and exploit new knowledge.

Specific human capital. With respect to owner specific human capital, we found that having started a business before adds to the new venture's export intensity, but an overall effect of being able to 'read' the market and understand its specific rules and regulations is lacking. After introducing absorptive capacity into the model, however, evidence emerged that the effect of both start-up experience and industry experience is largely dependent on the start-up's ability to adequately acquire, assimilate and exploit knowledge. More specifically, Figures 4 and 5 showed that while owner specific capital contributes to export intensity if organizational absorptive capacity is low, high absorptive capacity corresponds to a negative impact of owner specific human capital on export intensity, ceteris paribus.

Although we suspect that the effects of owner specific human capital, similar to general human capital, are equally conditioned by the organization's ability to acquire, assimilate and exploit knowledge, this fails to explain why absorptive capacity reverses the initial positive export impact of the owner's 
industry and start-up experience. We can only speculate about any (additional) mechanisms underlying this seemingly conflicting finding. A possible reason may lie in the definition of both specific human capital and this study's dependent. Remember that general human capital relates to knowledge that is useful and transferable across a wide range of situations. Specific human capital tends to be tailored to a more exact setting, which instills it with a much narrower scope of applicability (Gimeno et al., 1997). Hence, we suspect that precisely because specific human capital is more unique and inimitable, more venture- and market-related (the Belgian market) (Gimeno et al., 1997; Ucbasaran et al., 2008), it may turn out to be less transferable across national boundaries and less relevant to other than the initial context than originally anticipated. Thus, as the start-up's ability to make use of information increases, the organization might gradually come to realize that the owner's specific human capital is, in essence, largely domestically tailored and, therefore, not the most adequate driving force of internationalization and overall venture performance. Note that since this study's dependent represents a ratio, certain discrepancies between export intensity and overall venture performance may occur. As such, in an attempt to insure venture performance, a start-up with well-developed absorptive capacity may prefer to trim down its specific capital-induced export activities. Accordingly, our research seems to corroborate (and internationally expand) prior contributions that conclude that the relatedness of any human capital to the new venture is what produces a performance effect (Thorpe et al., 2005; West and Noel, 2009). Furthermore, the foreign market fine-tuning and transferability across regions of (specific) human capital may represent an interesting area of future research.

Surprisingly, and opposing earlier contributions (e.g. Autio et al., 2000; Bell et al., 2003), our results do not empirically confirm the (general) importance of industry experience to internationalization. A likely explanation for this finding may reside in this study's sampling conditions. As we mentioned before, internationalization research tends to have a penchant for high technological sectors and born-globals (e.g. IT and biotechnology). Our sample is a diverse one, both in terms of technology and industry. Hence, our results might suggest that the significance of industry experience for venture internationalization is in part dependent on the level of technology of the firm and/or its sector. Note that this is consistent with the emerging belief in entrepreneurship literature that early venture internationalization is evolving into a sector-specific and technology-bound phenomenon in which circumstantial elements such as industry and environmental characteristics (e.g. turbulence, dynamisms and munificence) exert a major influence. 
Bridging and bonding social capital. Summarizing our social capital findings, we discovered no effect of the owner's bridging and bonding social capital on the start-up's export intensity. Our study thus aligns with some of the preceding internationalization literature in which indicators of social capital have turned out to be equally insignificant in terms of new venture export development (e.g. Presutti et al., 2007; Yli-Renko et al., 2002). One possible explanation could be that it takes time for the business owner to construct a network of relationships, and even more time to distill valuable export information from it. Another, perhaps coexisting, interpretation might be that investments in social capital need time before their (true) effect becomes clear. Furthermore, within an internationalization context, the start-up may require very specific, foreign-market-tailored social capital rather than domestically developed weak and strong ties. As such, in order for the venture to benefit from the tangibles and intangibles provided by the owner, he/she may have to adapt his/her network so that it includes market-adjusted relationships that supply rare and precise information on the foreign opportunity. Unfortunately, we are unable to empirically validate this argument as our social capital measures do not take into account the international nature of the business owner's network, but future research could further explore this line of thought. Finally, there is also the possibility that the aid and advice from professional contacts (bridging social capital) and from family and friends (bonding social capital) offer the business owner little help when dealing with international issues.

The above findings should not be interpreted without some caveats in mind. First, our data might be biased with social desirability because our survey targeted a single respondent within each start-up, namely the start-up's business owner. However, the threat of common-method variance was weakened by the nature of the questionnaire (mixed type of questions) and the kind of measures employed, as they concern both factual and verifiable behaviors and events. Furthermore, it is difficult to judge causality based on a cross-sectional research design. Therefore, in order to validate the posited relationships, a longitudinal research design should be set up. Also, our measurement of absorptive capacity focused on market knowledge in general terms. A more specific measurement in terms of foreign market or export knowledge could prove to be beneficial. Finally, export activities were determined based on information provided by the respondent. While we expect this information to be fairly accurate, some deviations from reality may exist. 
Through our model and findings advanced in this article, we identify some additional opportunities for future research on top of the ones mentioned above. First, the role of absorptive capacity should be further disentangled. Research has already demonstrated that internal firm knowledge capabilities (such as knowledge sharing) have a different impact on the underlying dimensions of absorptive capacity (acquisition, assimilation and exploitation) (Jansen et al., 2005). Accordingly, modeling those sub-dimensions might increase our understanding of the impact and role of absorptive capacity on start-up internationalization. For instance, it could be that internationalizing start-ups first invest in developing the knowledge acquisition sub-dimension of absorptive capacity, whereas the strongest effects in terms of final impact on export and in terms of moderation may be reserved for the exploitation and/or assimilation sub-dimensions. Second, individual abilities that contribute to a firm's export intensity and international development should be further uncovered and investigated. Examples of additional indicators of human and social capital are the nature of the education, attendance at business classes, the number of organizations worked for, the amount of associations participating in, motivational factors and so on. Future research should incorporate the extent to which these human and social capital indicators are the result of non-domestic knowledge investments. Third, while our sample includes various sectors (manufacturing, transportation and professional services), there exist other economic sectors that are not represented in our study (e.g. agriculture, construction, and banking and insurances). As these remaining sectors might constitute an important part of economic activity, their international development should not be overlooked. Fourth, future research could seek to replicate the above findings in other countries and cultural contexts. Otherwise, the applicability of our study results remains restricted to the Flemish economy and culture which, even in a European context, is rather limited. Finally, researchers interested in the role of the business owner vis-à-vis the international development of their venture, might explore the internationalization effect of interactions between human and social capital indicators. For instance, the owner's education may induce a greater involvement in associations and easier access to others possessing scarce resources and knowledge (Dakhli and De Clercq, 2004), thereby influencing the international possibilities of the firm. 


\section{REFERENCES}

Aldrich, H., \& Zimmer, C. (1986). Entrepreneurship through social networks. In H. Aldrich (Ed.), Population perspectives on organizations (pp. 13-28). Uppsala: Acta Universitatis Upsaliensis.

Anderson, J.C., \& Gerbing, D.W. (1988). Structural equation modeling in practice: A review and recommended two-step approach. Psychological Bulletin, 103(3), 411-423.

Armario, J.M., Ruiz, D.M., \& Armario, E.M. (2008). Market orientation and internationalization in small and medium-sized enterprises. Journal of Small Business Management, 46(4), 485-511.

Arrègle, J.L., Hitt, M.A., Sirmon, D.G., \& Very, P. (2007). The development of organizational social capital: Attributes of family firms. Journal of Management Studies, 44(1), 73-95.

Autio, E., Sapienza, H.J., \& Almeida, J.G. (2000). Effects of age at entry, knowledge intensity, and imitability on international growth. Academy of Management Journal, 43(5), 909-924.

Barkema, H.G., \& Vermeulen, F. (1998). International expansion through startup or acquisition: A learning perspective. The Academy of Management Journal, 41(1), 7-26.

Barney, J. (1991). Firm resources and sustained competitive advantage. Journal of Management, 17(1), 99-120.

Baron, R.A., \& Tang, J. (2011). The role of entrepreneurs in firm-level innovation: Joint effects of positive affect, creativity, and environmental dynamism. Journal of Business Venturing, 26(1), 49-60.

Barringer, B.R., \& Bluedorn, A.C. (1999). The relationship between corporate entrepreneurship and strategic management. Strategic Management Journal, 20(5), 421-444.

Bates, T. (1990). Entrepreneur human capital inputs and small business longevity. Review of Economics and Statistics, 72(4), 551-559.

Becker, G.S. (1964). Human capital: A theoretical and empirical analysis, with special reference to education. Chicago, IL: University of Chicago Press.

Becker, G.S. (1993). Nobel lecture: The economic way of looking at behaviour. Journal of Political Economy, 101(3), 385-409.

Bell, J., McNaughton, R., Young, S., \& Crick, D. (2003). Towards an integrative model of small firm internationalization. Journal of International Entrepreneurship, 1(4), 339-362.

Bosma, N., van Praag, M., Thurik, R., \& de Wit, G. (2004). The value of human and social capital investments for the business performance of start-ups. Small Business Economics, 23(3), 227-236. 
Brush, C.G., \& Chaganti, R. (1999). Businesses without glamour? An analysis of resources on performance by size and age in small service and retail firms. Journal of Business Venturing, 14(3), 233-257.

Burgel, O., \& Murray, G.C. (2000). The international market entry choices of start-up companies in high-technology industries. Journal of International Marketing, 8(2), 33-62.

Burpitt, W.J., \& Rondinelli, D.A. (2000). Small firms' motivations for exporting: To earn and learn? Journal of Small Business Management, 38(4), $1-14$.

Chandler, G.N., \& Lyon, D.W. (2009). Involvement in knowledge-acquisition activities by venture team members and venture performance. Entrepreneurship: Theory $\mathcal{E}$ Practice, 33(3), 571-592.

Cohen, W.M., \& Levinthal, D.A. (1990). Absorptive capacity: A new perspective on learning and innovation. Administrative Science Quarterly, 35(1), 128-152.

Cooper, A.C., Gimeno-Gascon, F.J., \& Woo, C.Y. (1994). Initial human and financial capital as predictors of new venture performance. Journal of Business Venturing, 9(5), 371-395.

Dakhli, M., \& De Clercq, D. (2004). Human capital, social capital, and innovation: A multi-country study. Entrepreneurship $\mathcal{E}$ Regional Development, 16(2), 107-128.

Davidsson, P., \& Honig, B. (2003). The role of social and human capital among nascent entrepreneurs. Journal of Business Venturing, 18(3), 301-331.

De Clercq, D., Sapienza, H.J., \& Crijns, H. (2005). The internationalization of small and medium-sized firms. Small Business Economics, 24(4), 409-419.

Eriksson, K., \& Chetty, S. (2003). The effect of experience and absorptive capacity on foreign market knowledge. International Business Review, 12(6), 673-695.

Eriksson, K., Johanson, J., Majkard, A., \& Sharma, D. (1997). Experiential knowledge and cost in the internationalization process. Journal of International Business Studies, 28(2), 337-360.

Gimeno, J., Folta, T.B., Cooper, A.C., \& Woo, C.Y. (1997). Survival of the fittest? Entrepreneurial human capital and the persistence of underperforming firms. Administrative Science Quarterly, 42(4), 750-783.

Granovetter, M.S. (1985). Economic action and social structure: The problem of embeddedness. The American Journal of Sociology, 96(3), 589-625.

Hair, J.F., Anderson, R.E., Tatham, R.L., \& Black, W.C. (1998). Multivariate data analysis (5th edn.). Upper Saddle River, NJ: Prentice Hall.

Hatch, N., \& Dyer, J. (2004). Human capital and learning as a source of sustainable competitive advantage. Strategic Management Journal, 25(12), 1155-1178. 
Hitt, M.A., Uhlenbruck, K., \& Shimizu, K. (2006). The importance of resources in the internationalization of professional service firms: The good, the bad, and the ugly. Academy of Management Journal, 49(6), 1137-1157.

Hymer, S.H. (1976). A study of direct foreign investment. Cambridge, MA: MIT Press.

Jansen, J.P., Van den Bosch, F.A.J., \& Volberda, H.W. (2005). Managing potential and realized absorptive capacity: How do organizational antecedents matter? Academy of Management Journal, 48(6), 999-1015.

Johanson, J., \& Vahlne, J.E. (1990). The mechanism of internationalization. International Marketing Review, 7(4), 11-24.

Julien, P.A. \& Ramangalahy, C. (2003). Competitive strategy and performance of exploring SMEs: An empirical investigation of the impact of their export information search and competencies. Entrepreneurship: Theory $\mathcal{E}$ Practice, 27(3), 227-245.

Keh, H.T., Nguyen, T.T.M., \& Ng, H.P. (2007). The effects of entrepreneurial orientation and marketing information on the performance of SMEs. Journal of Business Venturing, 22(4), 592-611.

Kleinbaum, D.G., Kupper, L.L., Muller, K.E., \& Nizam, A. (1998). Applied regression analysis and other multivariable methods (3rd edn.). Pacific Grove, CA: Duxbury Press.

Knight, G.A., \& Cavusgil, S.T. (2004). Innovation, organizational capabilities, and the born-global firm. Journal of International Business Studies, 35(4), 124141.

Kohli, A.K., Jaworski, B.J., Kumar, A. (1993). Markor: A measure of market orientation. Journal of Marketing Research, 30(4), 467-477.

Lane, P.J., Koka, B.R., \& Pathak, S. (2006). The reification of absorptive capacity: A critical review and rejuvenation of the construct. Academy of Management Review, 31(4), 833-863.

Liao, J., Welsch, H., \& Stoica, M. (2003). Organizational absorptive capacity and responsiveness: An empirical investigation of growth-oriented SMEs. Entrepreneurship: Theory \& Practice, 28(1), 63-85.

Lu, J.W., \& Beamish, P.W. (2001). The internationalization and performance of SMEs. Strategic Management Journal, 22(6/7), 565-586.

Madsen, T.K. (1987). Empirical export performance studies: A review of conceptualizations and findings. In S.T. Cavusgil (Ed.), Advances in international marketing (pp. 177-198). Greenwich, CT: JAI Press.

Maes, J. \& Sels, L. (forthcoming). SMEs' radical product innovation: The role of internally and externally oriented knowledge capabilities. Journal of Small Business Management. 
Maes, J., Sels, L., \& Roodhooft, F. (2005). Modelling the link between management practices and financial performance. Evidence from small construction companies. Small Business Economics, 25(1), 17-34.

Manolova, T.S., Brush, C.G., Edelman, L.F., \& Greene, P.G. (2002). Internationalization of small firms: Personal factors revisited. International Small Business Journal, 20(1), 9-31.

McDougall, P.P., Shane, S., \& Oviatt, B.M. (1994). Explaining the formation of international new ventures: The limits of theories from international business research. Journal of Business Venturing, 9(6), 469-487.

Menon, A., Bharadwaj, S.G., Adidam, P.T., \& Edison, S.W. (1999). Antecedents and consequences of marketing strategy making: A model and a test. Journal of Marketing, 63(2), 18-40.

Moreno, A.M., \& Casillas, J.C. (2008). Entrepreneurial orientation and SMEs: A causal model. Entrepreneurship: Theory E Practice, 32(3), 507-528.

Mowery, D.G., Oxley, J.E., \& Silverman, B.S. (1996). Strategic alliances and interfirm knowledge transfer. Strategic Management Journal, 17, 77-91.

Muscio, A. (2007). The impact of absorptive capacity on SMEs' collaboration. Economics of Innovation \& New Technology, 16(8), 653-668.

Nahapiet, J., \& Ghoshal, S. (1998). Social capital, intellectual capital, and the organizational advantage. Academy of Management Review, 23(2), 242-266.

Oviatt, B.M., \& McDougall, P.P. (1997). Challenges for internationalization process theory: The case of international new ventures. Management International Review, 37(2), 85-99.

Oviatt, B.M., \& McDougall, P.P. (2005). Defining international entrepreneurship and modeling the speed of internationalization. Entrepreneurship: Theory E Practice, 29(5), 537-553.

Peng, M.W. (2001). The resource-based view and international business. Journal of Management, 27(6), 803-829.

Podsakoff, P.M., MacKenzie, S.B., Lee, J.Y., \& Podsakoff, N.P. (2003). Common method biases in behavioral research: A critical review of the literature and recommended remedies. Journal of Applied Psychology, 88(5), 879-903.

Presutti, M., Boari, C., \& Fratocchi, L. (2007). Knowledge acquisition and the foreign development of high-tech start-ups: A social capital approach. International Business Review, 16(1), 23-46.

Reuber, A.R., \& Fisher, E. (1997). The influence of the management team's international experience on the internationalization behavior of SMEs. Journal of International Business Studies, 28(4), 807-825.

Rialp, A., Rialp, J., \& Knight, G.A. (2005). The phenomenon of early internationalizing firms: What do we know after a decade (1993-2003) of scientific inquiry? International Business Review, 14(2), 147-166. 
Sapienza, H.J., Autio, E., George, G., \& Zahra, S.A. (2006). A capabilities perspective on the effects of early internationalization on firm survival and growth. Academy of Management Review, 31(4), 914-933.

Schultz, T.W. (1959). Investment in man: An economist's view. Social Service Review, 33(2), 109-117.

Shane, S., \& Khurana, K. (2003). Career experiences and firm founding. Industrial \& Corporate Change, 12(3), 519-543.

Smith, K.G., Collins, C.J., \& Clark, K.D. (2005). Existing knowledge, knowledge creation capability, and the rate of new product introduction in high-technology firms. Academy of Management Journal, 48(2), 346-357.

Sousa, C.M.P., Martinez-Lopez, F.J., \& Coelho, F. (2008). The determinants of export performance: A review of the research in the literature between 1998 and 2005. International Journal of Management Reviews, 10(4), 343-374.

Thorpe, R., Holt, R., Macpherson, A., \& Pittaway, L. (2005). Using knowledge within small and medium-sized firms: A systematic review of the evidence. International Journal of Management Reviews, 7(4), 257-281.

Tsai, W.P. (2001). Knowledge transfer in intra-organizational networks: Effects of network position and absorptive capacity on business unit innovation and performance. Academy of Management Journal, 44(5), 9961004.

Ucbasaran, D., Westhead, P., \& Wright, M. (2008). Opportunity identification and pursuit: Does an entrepreneur's human capital matter? Small Business Economics, 30(2), 153-173.

Verhees, F.J.H.M., \& Meulenberg, M.T.G. (2004). Market orientation, innovativeness, product innovation and performance in small firms. Journal of Small Business Management, 42(2), 134-154.

West, G.P.III, \& Noel, T.W. (2009). The impact of knowledge resources on new venture performance. Journal of Small Business Management, 47(1), 1-22.

Yli-Renko, H., Autio, E., \& Sapienza, H.J. (2001). Social capital, knowledge acquisition, and knowledge exploitation in young technology-based firms. Strategic Management Journal, 22(6/7), 587-613.

Yli-Renko, H., Autio, E., \& Tontti, V. (2002). Social capital, knowledge, and the international growth of technology-based new firms. International Business Review, 11(3), 279-304.

Yu, J., Gilbert, B.A., \& Oviatt, B.M. (2011). Effects of alliances, time, and network cohesion on the initiation of foreign sales by new ventures. Strategic Management Journal, 32(4), 424-446.

Zahra, S.A., \& George, G. (2002). Absorptive capacity: A review, reconceptualization and extension. Academy of Management Review, 27(2), 185-203. 
Zahra, S.A., Ireland, R.D., \& Hitt, M.A. (2000). International expansion by new venture firms: International diversity, mode of market entry, technological learning, and performance. Academy of Management Journal, 43(5), 925-950.

Zahra, S.A., Korri, J.S., \& Yu, J. (2005). Cognition and international entrepreneurship: Implications for research on international opportunity recognition and exploitation. International Business Review, 14(2), 129-146.

Zahra, S.A., Matherne, B.P., \& Carleton, J.M. (2003). Technological resource leveraging and the internationalisation of new ventures. Journal of International Entrepreneurship, 1(2), 163-186. 


\section{APPENDIX}

\section{Appendix B Factor loadings and Cronbach's alphas}

\begin{tabular}{|c|c|c|c|}
\hline & $\begin{array}{l}\text { Absorptive } \\
\text { capacity }\end{array}$ & $\begin{array}{l}\text { Bridging social } \\
\text { capital }\end{array}$ & $\begin{array}{l}\text { Bonding social } \\
\text { capital }\end{array}$ \\
\hline We have business meetings at least once every quarter to discuss market trends and developments. & .630 & .039 & .041 \\
\hline In this business, we meet with customers at least once a year to find out what products or services they will need in the future. & .587 & .120 & -.009 \\
\hline $\begin{array}{l}\text { The sales manager or owner-manager of our firm periodically spends time discussing customers' future needs with (other) } \\
\text { employees. }\end{array}$ & .759 & -.009 & .007 \\
\hline In this business, we do a lot of in-house market research. & .794 & -.070 & -.070 \\
\hline We periodically review our product development efforts to ensure that they are in line with what customers want. & .779 & -.082 & .036 \\
\hline We periodically get together to plan a response to changes taking place in our business environment. & .737 & .043 & -.024 \\
\hline Our business network enables us to identify market opportunities. & .054 & .753 & .097 \\
\hline Our business network is crucial for the further development of our company. & -.004 & .891 & -.080 \\
\hline Because of our business network, we have more customers. & -.031 & .889 & -.050 \\
\hline Our business network is crucial when looking for additional staff. & -.019 & .766 & -.026 \\
\hline We get support from family, friends and acquaintances when developing company policy. & .012 & -.090 & .814 \\
\hline Using family, friends and acquaintances, we acquire products and services cheaper and/or faster. & -.068 & .005 & .769 \\
\hline We often receive advice and support from professional friends on issues related to our company. & .055 & .347 & .429 \\
\hline Because of our family, friends and acquaintances, we are able to easily acquire external and/or wide-ranging financing. & .020 & -.025 & .782 \\
\hline $\mathbf{N}$ & 98 & 98 & 98 \\
\hline
\end{tabular}

Extraction Method: Principal Components Analysis; Promax rotation; To compute the factors we made use of the following formula to obtain one single score: $F=((S-V) /((V \cdot W)-V)) \times 100$ with $S$ equal to the sum of all initial values (before transformation), $V$ referring to the number of variables and $W$ representing the number of scale points (Maes et al., 2005). 